Seton Hall University eRepository@Seton Hall

Seton Hall University Dissertations and Theses (ETDs)

Seton Hall University Dissertations and Theses

2001

\title{
Clarity And Survival In The Zhuangzi
}

Thomas Radice

Seton Hall University

Follow this and additional works at: https://scholarship.shu.edu/dissertations

Part of the Asian Studies Commons

\section{Recommended Citation}

Radice, Thomas, "Clarity And Survival In The Zhuangzi" (2001). Seton Hall University Dissertations and Theses (ETDs). 1143.

https://scholarship.shu.edu/dissertations/1143 


\author{
BY \\ THOMAS RADICE \\ B. A, WEST CHESTER UNIVERSITY, 1995 \\ M. A., WEST CHESTER UNIVERSITY, 1997
}

\begin{abstract}
A THESIS
SUBMITTED IN PARTIAL FULFILLMENT OF THE REQUIREMENTS FOR THE DEGREE OF MASTER OF ARTS IN THE DEPARTMENT OF ASIAN STUDIES AT SETON HALL UNIVERSITY SOUTH ORANGE, NEW JERSEY DECEMBER 2001
\end{abstract}




\section{Aclmowledgements}

This thesis could not be completed if not for the generous support of many individuals along the way. It was their faith in my abilities that compelled me to persevere through the past two years.

Dr. Winston Yang, Dr. Shigeru Osuka, and Dr. Edwin Leung of the Department of Asian Studies at Seton Hall University were more than generous with their time and helpful advice throughout the writing process.

I could not have successfully struggled through the original Zhuangzi text without the guidance of Dr. Gilbert Mattos. He was generous enough to allow me a year of Classical Chinese study on just the Zhuangzi. I am grateful for the many enlightening discussions we had about its many textual ambiguities when considering possible translations.

Prof. M. C. Jenny witnessed the first working draft of "Clarity and Survival in the Zhuangz" when it was merely thirteen pages. She encouraged me to continue to work on it until it was presentable to conference audience.

Dr. Frank Hoffiman, my mentor at West Chester University, encouraged me to present an early version of "Clarity and Survival in the Zhuangzi" to the Society for Asian and Comparative Philosophy (SACP) at the Eastern Division Conference of the American Philosophical Association in 1999. As the commentator for our panel on "The Metaphysics of Experience," he provided constructive comments on how to improve the paper. In particular, I must credit Dr. Hoffman with bringing to my attention the apparent 
tension between the longing for survival and the courage to embrace death in the Zhuangzi. He also encouraged me to revise the paper for publication.

Another member of our panel, Dr. Paul Rakita Goldin, also provided constructive criticism on that paper and on an earlier draft of "Longevity and Transformation in the Zhuangzi," which was presented to the SACP the following year. He was also generous enough to serve as an external reader for the final version of this thesis.

Finally, Dr. Barry Blakeley went above and beyond the call of duty when be agreed to advise me even after he began his much deserved retirement. Thanks to modern technology and the U.S. Postal Service, we were able to communicate with each other from different ends of the country. Without his patience and good humor, this thesis would never have been completed.

Though all of these people have played a part in my writing and revising this thesis, all remaining errors are, of course, my own. 
Table of Conteats

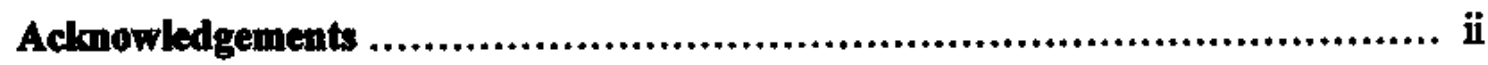

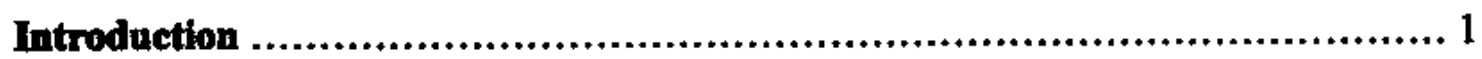

Outline of the Problem

Methodology

Review of Liternture

Chapter 1: Clarity in the Zhwangai

Clarity as Discernment

Clarity as Non-discermment

Clarity and Slence

Silence and Soteriology

Summary and Conclusion

Chapter 2: Longevity and Transformation in the Zhuangzi .................... 41

Death and Longevity

Death and Martyriom

Reconciling Death and Langevity

Uselessness and Skilliulness

Conclusion

55

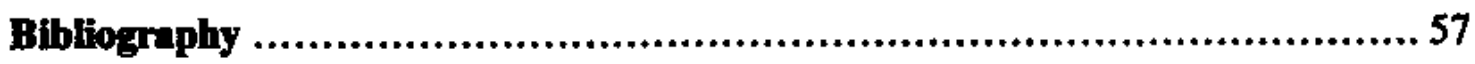




\section{Introduction}

\section{Ointine of the Problem}

This thesis is a study of the concept of ming 明 and the theme of survival in the Zhuongai 菲子: ${ }^{1}$ Ming has received far less scholarly attention than ren 仁, de 德, xiao 若, and many other philosophical terms. The character for ming is a combination of $r i$ 日 (an) and yue 月 (moon) to literally mean "bright," but it can also be translated as "clear," "clarity," "illumimation," or "hweidity." Its meaning, though, is not restricted to things pertaining to light. As in many languages and cultures, the metaphor of "light" is commonly used for "understanding" or "seeing" something as it really is. For example, referring to "clarity," the American philosopher C.S. Peince says, "A clear idea is defined as one which is so apprehended that it will be recognized wherever it is met with, and so that no other will be mistaken for it. If it fails of this clearness, it is said to be obscure."2 In the Zhuangzi, however, the concept of "clarity" (ming) itself is often obscure. But the question is not simply "what is ming?", but rather "what does it mean to use ming?" or "what kind of knowledge does ming provide?"

Survival, by contrast, is not so much a concept as it is a theme in the Zhuangzi, since it is not limited to a single term. By "survival" I mean the "avoidance of death" and "longevity." The text makes broad references to the value of survival; but unlike ming it is not something that is debated. That is, no one asks "what is survival?" Thus, the question

\footnotetext{
'This thesis is an elaboration of my article, "Clarity and Survival in the Znucangzi," Astan Philosophy $11.1(2001): 33-40$.

${ }^{2}$ C.S. Peirce, "How to Make Our Ideas Clear," Popular Sclence Vol. 12 (1878): 286-302. Reprinted in Contemporary Analytic and Linguistic Philasophtes, ed. E. D. Klemke (Amherst, NY: Prometheus Books, 1983), 55 (page eitation is to the roprint).
} 
is "what is its significance of survival in the Zhuangzi?" and "bow does this significance compare to its significance in other Chinese philosophical texts?" Part of its significance in the Zhuangzi is an apparent tension with the theme of death. Generally one contrasts survival and death in such a way that implicit vahue judgments are made (i.e., survival is good, death is bad). One's sense of "self-preservation" is one's unconscious, if not conscious, attempt to avoid death ${ }^{3}$ TheZhuangzi, however, does not disparage death. It sees death as a constituent part of the process of life. To accept life is to accept death, and yet try to lead a long natural life.

Ultimately, I will show that ming and survival are connected in the Zhuangzi. The attainment of ming leads to the emphasis on survival, and the comprehension of the importance of survival is dependent upon the understanding of ming. The sage uses ming to realize the unity of opposites and the relativity of distinctions. Ming is the "illumination" of this meta-philosophical perspective. This realization in turn leads to the renunciation of public affairs, since public affairs requires the making of distinctions and value judgments. Renunciation leads to "uselessness," and "uselessness" leads to survival. The emphasis on uselessness/survival requires an "amoral" interpretation of ming. Survival is rarely a criterion for moral action. If anything, sturvival is usually sacrificed for the sake of morality governed by virtue, duty, or the greatest good. If survival is considered at all, it is the survival of the group, not personal survival. Therefore if personal survival is the ultimate and most important result of ming, then ming cannot be

\footnotetext{
${ }^{3}$ For a contemporary philosophical and psychological study of the humanity's fear of denth, seo Ernest Becker, The Dental of Dewh (New Yoik: The Free Press, 1973).

${ }^{4}$ Here I refer to the view of traditional utilitarian ethics developed by Jeremy Bentham and John Stuart Mill, who argue that one must always act 30 as to create the greatest good for the greatest number of people.
} 
conceived as a moral concept. Rather, ming will be shown to have a soteriological function

\section{Methodology}

Though intellectual history and philosophy are not always easily distinguishable (and that may not be a bad thing), this study is an exercise in the former.' In other words, I am concerned with explicating the thought of the Zhuangzi, not using the text as a springboard into my own ideas about "clarity" and "survival" or expounding upon the contemporary relevance of the Zhuangzi. Though such endeavors have their place, my project is more conservative and preliminary. In order to apply the ideas of the Zhuangzi (or even develop them), one must first figure out what it says - and that in itself is difficult. But my historical emphasis is not entirely uncritical. My criticism is focussed on the internal coherence of the Zhuangzi's ideas. Thus, as with any text, the ideal interpretation will (to the greatest extent possible) reconcile apparently conflicting passages.

This task is not easy. Like nearly all early Chinese philosophical texts, the Zhuangzi is a heterogeneous work containing contradictory viewpoints. Tradition attributes authorship of the entire text to Zhuang Zhou 荘周, for whom reliable biographical data is scarce. The Shiji 史記 states that he was a contemporary of King Hui

\footnotetext{
SScholars who research Asian philosophy and religion typically fall into two camps: those who call themselves (comparative) philosophers and those who call themselves intellectual historions. If feel that the two disciplines are hard to distinguish because both require the other in ordar to mako any sense of their subjects; that is, one must know some intellectual history to do philosophy and one must know some philosophy to do intellectual history. Philosophess need history so as not to aseribe ideas to people who could never have thought thean, and historians need philosophy to offer a foumdational vocabulary (oven if it may be inadequate at times) with which to describe and compare ideas.
} 
忽 of Liang 梁(370-319 B.C.E.) and King Xuan 宜 of Qi 产(319-301 B.C.E.).

However, the biography of Zhuang Zhou in the Shiji was composed over two centuries after he supposedly lived, and there is little useful information on his life from other sources. Furthermore, it is abundantly clear that the Zhuangzi was written by several authors, although scholars still disagree on the exact dating and categorization of the text.

A.C. Graham and Liu Xisogan (among others) have proposed theories of the texts composition and authorship. ${ }^{6}$ Both agree with popular scholarly opinion that the Inner Chapters $(1-7)$ are the earliest and were probably written by the historical Zhuangzi. For this reason, these chapters are the most analyzed of the entire extant colition of thirty-three chapters. Graham and Liu also agree that a portion of the Outer and Miscellaneous Chapters were written by later followers of Zhuangzi's school (roughly $12-16$ and perhaps 33). They disagree, however, over the nature of the chapters that do not correspond to the later school of Zhuangzi. Graham divides them into separate schools: Primitivist, Syncretist, and Yangist. The Primitivist chapters aspire for a "detechnologized" society, one that has done away with the umecessary (if not destructive) moral distinctions of the Confucians and Mohists. This view is illustrated in Chapters 8 10 and also parts of Chapters 11 and 12. ${ }^{7}$ The Yangists emphasize a good life - "good" in the sense of "pleasurable" - and a rejection of moralism in politics. These ideas are prevalent in Chapters $28-31 .^{8}$ Finally the Syncretists, who according to Graham and others, probably compiled the text, tried to reconcile and synthesize Confucian and Daoist

\footnotetext{
"A.C. Graham, "How Much of Chuang-ky Did Chuang-tza Write?" in Studies in Chinese Philasophy and Phtlasophical Literature (Albeny: SUNY Press, 1990), 283-321. Liu Xiaogan, Classifying the Zhuangzi Chapters (Ann Arbor, MI: Center for Chinese Studies, The University of Michigan, 1994).

${ }^{7}$ Graham, 303.

I Ibid., 313.
} 
thought. Elsewhere, there is a characteristically Daoist passivity when it comes to life and nature, but a clear dominant Confucian tendency to moralize and value active social involvement. These ideas fall roughly in line with Chapters $16-27 .^{9}$

Liu angues that these views are not separate schools per se, but rather later divisions within the Daoist school. He terms them "Huang-Lao" and "Anarchist." The Huang-Lao roughly correspond to Graham's Syncretists in that both incorporate elements of Confucianism and Legalism. The Anarchists, by contrast, redically oppose Confucianism and Mohism, and roughly correspond to Graham's Yangist (and some Primitivist) chapters. Liu also opposes Graham's piecemeal approach to the Outer and Miscellaneous Chapters. ${ }^{10}$ Overall, he argues that the entire Zhuangzi as a Daoist text despite its heterogeneity, which can be explained away as liter disagreement among later followers of Zhuangzi ${ }^{11}$

These differences aside, both Graham and Liu agree that the Inner Chapters are the earliest. But there are scholars who suggest that perhaps even the Inner Chapters were written by more than one author. ${ }^{12}$ I do not intend to solve this issuc bere; suffice it to say that I take the prudent step of referring to the Zhuangzi, rather than Zhuangzi, except when referring to the character of Zhuangzi, the man. ${ }^{13}$ My anslysis focuses on the Inner

\footnotetext{
'Ibid., 318-321.

${ }^{10} \mathrm{Linu}, 167$.

11 Ibid., 169.

12 In a review of Liu's book, for example, C.J. Fraser criticizes Liu for to dismiasing too quickly Zhang Hengshou's multiplo-author hypothesis about Chapter 4, See C.J. Fraser, Reviow of Claseifying the Zhuangal Chapters, by Liu Xiaogan, Aston Philosophy 7.2 (1997): 155-159.

${ }^{13}$ This should not be a problem, since texts need not be attributed single authars to maintain ocherence. The Zluargat's format even marks a transition in philosophical writing during the Warring States, since unlike the Lun yu and the Menciss, it is not a series dialogues with a master. With the incorporation of essays and aneodotes, Mark Edward Lowis argues that it and litter texts (like the Xunzi and Han Feizn) "yugest that with the emergence of traditions that did not form strong associntions, the teaching scene became secondary to textual transmission. ... In a world of competing traditions, the authority of
} 
Chapters, since they are considered the earliest and most homogeneous. I contrast the use of ming in the Inner Chapters with its use in those parts of the Outer and Miscellaneous Chapters not attributed to the later followers of Zhuangzi. I also occasionally use parts that are attributed to the later followers of Zhuangzi as clarification of potential philosophical problems in the Inner Chapters. This is the common approach of most scholars, though (as discussed below) it does not necessarity cause them to arrive at the same conchusions.

\section{Review of Literature}

Chad Hansen's interpretation of the Zhuangzi is one of the most controversial ${ }^{14}$ He begins by arguing that the Zhuangzi proposes a view he calls "perspectival relativism" That is, there are many perspectives about reality and no perspective is better than any other, or at least there is no standard by which to judge one as better or more accurate than another. He also argues that doo 道 should be understood as linguistic rather than metaphysical, which leads him to interpret dao as "guiding discourse." 15 Every philosopher has a dao. Therefore, there are many different ways of talking about reality.

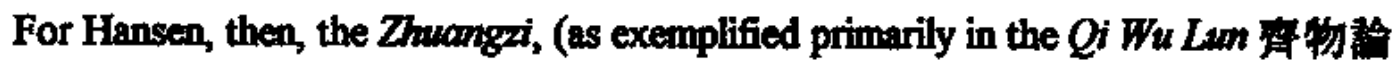
chapter) argues not for any specific dao, but rather that all dao are equal.

Crities like Philip J. Ivanhoe, however, defend the traditional metaphysical interpretation of dao in the Zhuangzi. Arguing directly against Hansen, Ivanhoe asserts

individual masters took second place to the peranasive power of arguments, and tight teacher-disciple bonds were replaced by more open, text-based groupings." See his Witing and Authority in Eorly China (Albany: SUNY, 1999), 62.

it Chad Hansen, "A Too of Tao in Chusng-tza" in Experimertal Essags on Chuang-tru, ed. Victor H. Mair, (Honolulu: University of Hewaii Press, 1983), 24-55. 
that dao is "the deep structure of the pattern and processes of the world." In a conceptual defense of this position, he notes that the Znuangzi often recognizes ways of living that are contrary to dao, and yet people who follow dao are model human beings. This would be impossible if the Zhuangzi wanted to maintain a consistent relativist position.

Hansen also wants to say that the Zhuangzi sees everything from a "god's eye" view. From this position, nothing matters and there is no reason to choose one course of action over another. But though the Zhuangzi often mentions this completely "objective" view, Ivanhoe says it never recommends we give up the human point of view. Therefore, Ivanhoe would rather interpret the "heavenly" perspective as "therapeutic," intended to "curb our tendency toward self-aggrandizment."17 Furthermore, though one can believe all things are equal from a "heavenly" perspective, once can still believe there are better and worse lifestyles. The heavenly perspective keeps us in check when we become "full of ourselves."

Though Hansen's original article attracted heavy criticism, he reiterated and developed his position in a book, A Daoist Theory of Chinese Thought, by offering explanations of terms like ming and dacsinu 道撞. Ming, according to Hansen, is a metaview of the role of language in governing distinctions and attitudes. ${ }^{18}$ It does not lead to some "transcendental mystical sort of knowledge." Rather, it is the understanding of the nature of perspectives, a part of the Zhuangzi's theory of the "indexicality of

\footnotetext{
${ }^{15}$ Ibid, 35.

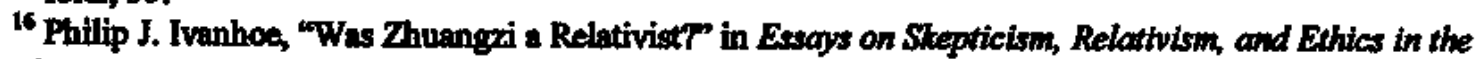
Zhuoungzi, eds. Paul Kjellberg and Philip J. Ivanhoe (Albany: SUNY, 1996), 201.

${ }_{17}$ Ibid, 200.

"Ibid, 281.
} 
language." According to Hansen, indexicals "are terms in a language whose reference changes with the features of the context." "before" change their reference as each moment passes. Hansen says that the Zhuongzl's concept of ming depends upon the view that all language is indexical. ${ }^{21}$ The use of language depends more on the perspective of the user than on the world. Therefore, all things are in themselves both shi 是 and not shi ("so" and "not so," "acceptable" and "not acceptable"). Whether something is shi or not shi depends on the particular dao one follows.

One's particular dao begins at daoshu or "hinge of dao." Hansen describes daoshu as a "hypothetical, unbiased purely non-purposive perspective that is prior to any system of language.,22 It is not that nothing can be said from this perspective, rather that anything can be said. Once something is said, one steps off this "hinge" or "axis" onto a particular dao. One can step off in any direction, so that in effect there is no limit to the number of possible ways of talking about the world, and all have equal warrant..$^{23}$

Alan Fox overs another view of ming and dooshu. He uses ming and daoshu to illuminate wrwei 無爲(literally, "non-action") in the Zhuongzi and to explain the behavior of the Zhuangzi's ideal person. He links wuwei with the xiacoyao 遮滔 ("rambling/meandering") of the Sage. According to Fox, xiaoyao implies a "metaphysical" flexibility. That is, it is not merely a way of acting, but also a way of approaching the world. For this reason, Fox claims that wrwei/xiaoyao is a way of

\footnotetext{
${ }^{19}$ Ibid., 282.

20 Bid.

${ }^{21}$ Ibid.

${ }^{22}$ Chad Hansen, A Daoist Theory of Chinese Though (New York: Oxfind Univusity Press, 1992), 283.

2 Ibid.
} 
matching attitude with circumstance. 24 This kind of "attitude matching" requires shifting contexts and seeing things from new perspectives. As an example, Fox notes the story of Zhuangzi and Huizi's discussion of the gound in Chapter 1. In this story, Huizi tells Zhuangzi of the a huge gourd that was too big to make into water containers or even dippers. Since the gourds were so big, Huizi smashes them to bits. Zhuangzi replies that Huizi should have tried making the gourd into a huge tub and go floating around rivers and lakes. ${ }^{25}$ He says that Huizi's view of the gourd is too fixed, and Huizi umable to see bow it could be used in a new context. Zhuangzi's ability to do so allows him to solve problems more easily with greater peace of mind.

Therefore (pace Hansen), Fox rejects perspectival relativism. Each unique situation carries its own limitations and inevitabilities, which need to be accommodated. There may be no single right or wrong, but there are actions that are "most right or wrong given particular constraints. ${ }^{26}$ Situations are not entirely relative or absolute. The key is finding the "path of least resistance" or "finding the fit" (i.e., adapting to change). ${ }^{27}$ Wuwel, then, is a kind of "frictionless activity" that leads to the greatest contentment." This "frictionless activity" is linked to daoshu, since it is within daashu that one sees dichotomies as complements, not opposites. The insight into the complementary nature of opposites is ming. ${ }^{29}$ Through ming, people do not identify with their evaluations, but

\footnotetext{
${ }^{24}$ Alan Fax, "Reflex and Reflectivity: Wuwei in the Zuvanga" Astan Phllasophy 6.1 (1996), 61.

${ }^{25}$ See Burton Watson, The Complete Works of Chuong TuU (New York: Columbia University Press, 1968), 35.

Fox, 62 .

27 pid.

23 Ibid., 64.

${ }^{2}$ Ibid., 65.
} 
watch as all distinctions revolve around the single standpoint of daoshu. Ming, then, permits effortless adaptation to any situation.

Another non-relativist theory of ming comes from A.S. Cua, who links it the notion of wang 忘 (to forget). This notion of forgetting is central to what he calls "dao experience. ${ }^{230}$ His explanation consists primarily in reconciling this "forgetting" with Gilbert Ryle's claim that "forgetting" right and wrong is absurd." To argue this point, Ryle distinguishes between two kinds of forgetting: (1) loss of memory, and (2) to not pay attention to or neglect. "Forgetting" in the Zhuangzi is like the second kind (i.e., ceasing to pay attention to moral distinctions in the way ordinary moral agents care for them). In this way, ming is not a form of ethical relativism, but rather a critique of fixed principles of conduct. Like Fox, Cua's view of ming sces opposing moral theories as complementary rather than contrary or contradictory. Therefore, "forgetting" is not a reflection of our moral vocabulary or moral knowledge, but rather the recognition of our tendency to erect exclusive disjunctions. ${ }^{32}$ But Cua warns that this sense of "forgetting" does not mean simply ceasing to care. It means ceasing to care in a certain way. Again like Fox, it is the development of a meta-moral attitude - what Cua calls "dao-attitude. ${ }^{33}$

Cua describes dao-attitude in terms of "forgiveness." To forgive is to "forget" a wrongdoing of another in the sense of "ceasing to care." The act of forgiveness preserves the moral distinction by judging an act as wrong. However, it also withholds any further consequences that normally follow the application of moral distinctions. In this way,

\footnotetext{
${ }^{30}$ A.S.Cup "Forgetting Morality: Reflections on a Theme in Chumg Tzu," in Moral Vision and Tradtion: Esseays in Chinese Euhics (Washington, D.C.: Catholic University of America Press, 1996), 37. ${ }^{31}$ See Gilbert Ryle, "On Forgetting the Difference Betweon Right and Wrong." in Esesens in Moral Phillosophy, of. A. I. Melden (Seattle: University of Washingten Press, 1958), 21-40.

${ }^{32}$ Cus, 48.
} 
according to Cua, dao-attitude stresses harmony between persons. ${ }^{34}$ Unlike Fox, then, this dao-attitude is not so much a way of making moral decisions as it is reconciling conflicting perspectives of individuals. It a way of allowing people to live together harmoniously in spite of their differences. As Cua puts it, dao-attitude "is essentially a person-directed rather than a subject directed attitude. ${ }^{\text {35 }}$ Cua maintains an emphasis on the moral character of ming, but not in the sense of a normative decision making process.

The decision-making process interpretation is maintained by William A. Callahan, who explains ming in conjunction with the "whetstone/potter's wheel of nature" to provide a technique for addressing problems when the "conventional approaches" fail. Decisions are made by "interchanging the alternatives and harmonizing them with the situation at hand in order to make a contextual decision." According to Callahan, ming is the "interchange" or "intercommunication" of shilfei 是/非("this"/"not this"). ${ }^{37}$ This "interchange" of shi/fei is also the "interchange" of perspectives from which shi/fei is made, which, similar to the ideas of Fox and Cua, shifts the focus from differences to similarities.

Also tike Fox, Callshan links ming to daoshu, but claims it refers to that which is "outside the cosmos," "beyond the realm of things," "beyond guidelines."3t This notion of ming (like Hansen's view) is pre-linguistic in a context that does not contain shi and fei relative to a certain situation - there is no situation; there is no speech. This ming is not

\footnotetext{
${ }^{31}$ Ibid., 51.

${ }^{34}$ Ibid., 54.

${ }^{33}$ Ibid.

${ }^{36}$ William A Callahan, "Cock Ding's Life on the Whetstone," in Wandering at Ease in the Zhuangzi, ed. Roger T. Ames (Albemy: SUNY, 1998), 183.

37 lbid.

3* Ibid., 186.
} 
concerned with action, but with potential action. It is through "stepping off" daoshu that one determines a perspective (shilfel). ${ }^{39}$

By contrast, ming "within the cosmos" is illustrated by the "whetstone of nature" (tion ni 天倪) and the "potter's wheel of nature" (tion jun 天均), both found in Chapter 2. In the case of the "whetstone of nature," no common ground can be found to settle a dispute. ${ }^{40}$ According to Callahan's interpretation, resolution can only come from a "pragmatic harmonizing of the contextual particulars" to see what works best." In the case of the "potter's wheel of nature," a monkey trainer appeases his monkeys through "interchange." Success comes from the keeper's hack of attachment to a single feeding pattern (either three nuts or four nuts). By "interchanging" to what monkeys approve of, the monkey keeper embodies ming to solve this simple problem.

A more complex illustration of ming common to all the above interpreters (except Cua), is the story in Chapter 3 of the cook who amazes Lord Wenhui with his butchering of an ox. The cook carves the ox effortlessly, explaining afterward that he merely follows dao, which is "beyond skill" The challenge for interpreters of the Zhuangzi"s view of dao is to explain how the cook makes his decisions while carving the ox.

Hansen uses this story to maintain his argument against what he calls the popular "monistic absolutist view of dao." ${ }^{, 3} \mathrm{He}$ argues that the story of the cook in Chapter 3 conflicts with this view, because the cook does not master an "absolute" dao, but rather a particular dao among many possible ones. And Hansen, in order to remain consistemt with

\footnotetext{
${ }^{39}$ Ibid., 187.

${ }^{10}$ See Watson, 33-34.

${ }^{41}$ Callahen, 185.

4 See Watson, 36.

${ }^{43}$ Hansen, Daoist, 287-288.
} 
his interpretation of Chapter 2, chaims that one cannot even say that the cook masters butchering, but merely a style of butchering. " In the end, this story illustrates a more "pragmatic" view of dao (i.e., mastering any dao that works). 4

Fox, however, uses this story not to argue for any dao, but rather to show how through dao one is not constrained to a single response to situations. Under Fox's interpretation, the cook inevitably slips into the most natural shi. Finding the most natural shi is like finding a "fit," as in the "hinge of the dao" (daoshu). The perspective of daoshu "permits effective and effortless adaptation to circumstances and conditions." Without the burden of set standards or rules the cook can perform his job in a more natural and spontaneous manner. However, as Fox stresses, the cook is not "free" in the sense of "freedom to" do what he wants, but rather "freedom from" committing to a set formula. In other words, the cook does not cut wherever he wants. He "finds the spaces between the bones. ${ }^{\text {"77 }}$

Under Callahan's view, when the cook comes across difficult situations (i.e., when he cannot use his "usual" butchering skills), he must call upon ming and the potter's wheel of nature. He pauses on the potter's wheel, interchanging all the possible shi and fei until he is satisfied with a course of action He is successful because he can hold on to his learned skills, but not so tightly that he cannot move to new "discourses" when his ordinary skills are not usefill ${ }^{48}$ Contrary to Fox's interpretation, however, any new course of action (or "discourses") is only decided upon after a period of deliberation. In this

\footnotetext{
${ }^{4}$ Ibid., 289.

${ }^{45}$ Ibid., 288.

${ }^{46} \mathrm{Fox}, 65$.

17 Ibid., 64 .

Callahan, 192.
} 
sense, Callahan's view is similar to Hansen's pragmatism, but in a far less relativistic sense, insofar as Callahan does believe (like Fox) that some courses of action are better than others. All three interpretations involve decision making, but Callahan's view is the most systematic (for lack of a better term).

And yet, Callahan associates the "Utmost Person" (zhenren 设) with the inaction of daoshu. Callahan asserts that the zhenren reflects the limitless potential of shilfei within daoshu." The zhenren "has no self" (i.e., no selfother distinction) like the lack of shilfei in daoshu. Consequently, the zhenren resides in inaction (a more literal whwei than Fox's interpretation), for to take action would create distinctions. ${ }^{\text {so }}$

A more complex interpretation of the zhenren comes from Lee Yearley, who distinguishes two different views in the Zhuangzi - the conventional and the radical. According to Yearley, the conventional view argues that humans should recognize four related things about themselves: 1) diverse ways of existing appear in the world, 2) no standard exists by which to judge these different ways of existing, 3) everything in the world is in continuous change, and 4) each humen exists in a particular way at a particular time." Under this view people should enjoy everything as it is for what it is, but they should not place any lasting value in anything. People do not act any differently than usual. They differ from others only in how they view what they do, which only becomes clear if an extraordinary event occurs. ${ }^{52}$

\footnotetext{
${ }^{49}$ lbid., 188.

${ }^{50}$ Ibid., 189.

"Lee Yearloy, "The Perfected Person in the Radical Chuang-tzu," in Experimental Escons on Chuangtzu, ed. Victor H. Mair (Honolulu; University of Hawail Press, 1983), 128-129.

32 Ibid., 129.
} 
The radical view in the Zhuangzi, however, represents a distinctive form of mysticism, which differs from other forms of mysticism in South Asia and the West. According to Yearley, in the mysticism of the Roman Catholic tradition (from the thirteenth century on), there is a union between two separate realities: transcendent reality and the contingent but real world. ${ }^{53} \mathrm{~A}$ "union" but not a "unity" exists between the unchanging Real and the changing particular individual. In other words, there is separation between the two realms. This separation exists because the mystic needs the higher power's help in order to reach and maintain the goal of mystic union. ${ }^{\text {s4 }}$

In the mysticism prevalent in South Asia, however, only one reality exists, and no particular object is fully real. In this mystical experience, the individual's differentiating characteristics drop awny, revealing a oneness. This mystic needs no help from the sacred reality, in which the goal is indeed a unity. ${ }^{35}$

Contrary to both these forms of mysticism, in the "intraworklly" mysticism of the Zhuangzi, there is neither a union with a separate transcendent reality, nor a unity with a single reality. Instead, this form of mysticism aims to see the world in a new way. ${ }^{36}$ Mystical experiences are not valuable in themselves. They are valuable only insofar as they help someone obtain a new viewpoint on normal experience.".7

Yearley then argues that the Zhuangzi uses two images to explain this form of mysticism: the "axis of a circle/"hinge in a socket" (daoshu) and a mirror. Daoshu moves continuously and responds endlessly. In other words, says Yearley, it does not pass

\footnotetext{
${ }^{53}$ Ibid., 130.

st Ibid, 131.

ss Ibid.

36 Ibid

${ }^{57} \mathrm{Ibid}$.
} 
judgment. $^{\text {so }}$ The mirror accepts whatever is presented to it without interpretation. It simply reflects what is there. These images are important, because "normal language" implies contraries (shilfei). Instead, the Zhuangzi uses the images to "picture" the perfected mind."

In a more recent essay, Yearley connects this mysticism (or what he calls the "ultimate spiritual state") to parts of the Zhuangzi that deal with skilful action. He distinguishes two kinds of action: "processes" and "performances." A process is goal oriented. Fulfillment comes only when that goal is achieved. ${ }^{60}$ In performance, however, each part of the activity is complete in itself. Fulfillment comes only through the performance. ${ }^{61}$ Yearley uses this distinction to claim that normal actions are processes animated by external goals, while skillful actions are performances. ${ }^{62}$

In addition to these two types of actions, Yearley distinguishes two types of knowledge: "knowledge that" and "knowledge how." "Knowledge that" is to have information, to obtain it suddenly (e.g., by reading), and to judge its worth by the criterion of truth and falsity (e.g., I know that I should change my spark plugs, and I know that the Zhuangzi says to have a mind like a mirror). ${ }^{63}$ The acquisition of "knowlege how," however, comes through habituation; that is, repeated action. ${ }^{64}$ Skilful action utilizes "knowledge how," but it is not simple repetition. According to Yearley, it includes

\footnotetext{
Ibid., 132.

Ibid, 134 .

${ }^{60} \mathrm{~L} \infty \mathrm{H}$. Yearley, "Zhuangzi's Understanding of Skillfulness and the Ultimate Spiritual State," in Essays on Stepticism, Relativism, and Ethics in the Zhuanged, eds. Paul Xjellberg and Philip J. Ivanhoe (Albany: SUNY, 1996), 168.

GI Ibid.

62 Ibid., 169.

Ibid., 170.

${ }^{64}$ Ibid.
} 
alertness and adaptation to changing situations, which seems to bring him close to the views of the interpreters discussed above. ${ }^{65}$

Where Yearley differs from other interpreters is in his discussion of "transcendent drives." This idea is important, because Yearley recognizes that the ultimate spiritual state for the Zhuangzl is beyond skill ${ }^{66}$ He distinguishes these transcendent drives from "dispositional" and "reflective" drives. Dispositional drives involve strong movements to action that are triggered by specific circumstances. These may inchude biological states like hunger or sociological conditioning like deference to elders. ${ }^{67}$ Reflective drives manifest the desire to have different drives than the dispositional ones (c.g., to become a person who is not easily angered)..$^{68}$

Transcendent drives are different, says Yearley, because they "generate activities that exceed the normal capacities of the self and seem to rise beyond it. ${ }^{.69}$ They resemble dispositional drives in their strength and spontaneity and arise only because reflective drives lead to a fundamental change in the self. Finally, however, they dissolve both dispositional and reflective drives to, in effect, dissolve the normal self to bring it "the highest possible spiritual fulfilment."

In the terminology of the Zhuangzi, Yearley links transcendent drives to shen 神 ("daemonic" or "spiritual"). Shen represents a higher kind of ability, illustrated by the

\footnotetext{
${ }^{65}$ Ibid., 171.

${ }^{6}$ lbid, 174. See also Watson, 46.

${ }^{67}$ Yearley, "Skilliulnews," 153.

"Ibid., 154.

Ibid.

${ }^{70}$ Ibid.
} 
cook. But the key contribution of Yearely is his assertion that shen is amoral - if conventional moral standards are the measure. ${ }^{71}$

Yearley's distinction between different drives is similar to Eno's distinction between "theoretical knowing" and "practical knowing," which leads the two to similar conclusions. Eno describes theoretical knowing as "rigid, unresponsive, and limited by its own arbitrary rules. ${ }^{\text {72 }}$ It blinds us to that which cannot be expressed by theory. Practical knowing (which the Zhuangzi promotes) is "dynamic, responsive, and improvisatory. ${ }^{\text {n3 }}$ It is free of fixed rules and embodies skillful activity. Eno interprets Chapter 2 of the Zhuangzl as an argument against theoretical knowledge in favor of practical knowledge. The chapter argues that one camnot use language to acquire authentic knowledge. As for ming, Eno interprets "the use of ming" (yi ming 以明) through the line "The sage lodges his affirmation in 'ordinary practice' (yong in $\left.^{\text {) }}\right)^{{ }^{74}}$ Eno is also convinced that this chapter lays the groundwork for the third chapter in which the cook shows how skilled practice leads to authentic knowledge. The cook's contact with the world is characterized by shen $y u$ 神遇 ("a spirit-like encounter"), and no longer governed by guan zhi 官知("the reflective awareness of his senses" $).^{75}$ Like Yearley's transcendent drives, Eno's view of shen is beyond skill. And contrary to the relativism of Chapter 2, the third chapter's positive judgement on skill knowing is nomrelativistic. ${ }^{76}$

\footnotetext{
${ }^{71}$ Ibid., 176.

${ }^{72}$ Robert Eno, "Cook Ding's Dao and the Limits of Philosophy," in Estays on Strepticism, Relativism, and Ethics in the Zhuangzd, edis. Paul Kjellberg and Philip J. Kvanhoe (Albany. SUNY, 1996), 127. ${ }^{13}$ Ibid.

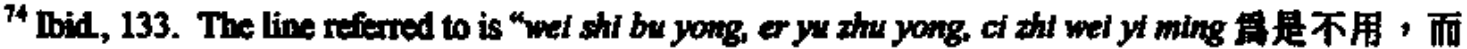

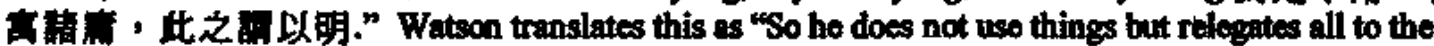
constant [yong fif]. This is what it means to use clarity," 38.

${ }^{75}$ Eng, 135.

${ }^{76}$ Ibid., 136.
} 
Yet Eno notes that the Zhuangzi does not propose any "cardinal dao." While the text offers examples of ideal individuals (those who fly, live on air and dew, walk on fire unburned), it never states specifically and methodically in any direct language how these people achieve their focus and power. Thus contrary to many of the interpreters above, but similar to Yearley, Eno does not see the Zhuangzi proposing any theory that would allow one to transform this valuation of skill into a coherent ethical theory. ${ }^{n}$ Eno's point is significant, because it reveals the difficulty in reading moral theory (even a relativist moral theory) into the Zhuangzi.

In line with this view, one shortcoming of the contextualist positions of Ivanhoe, Callahan, and Fox is that they seem to ignore the ubiquitous notion of "uselessness" in the text, which seems to go against any "moral" reading of the Zhuangzi. John Major, for instance, points out that for the Zhuangzi, "uselessness" (bu cai 不材, wu suo yong 無所 用) is the key to survival in the turbulent Warring States. ${ }^{79}$ He notes that this idea is virtually absent in the West, especially in Western ethics. But he also notices an apparent paradox about the Zhuangzi's advocacy of uselessness. In some cases, the text advocates uselessness over usefulness. In other cases, the text advocates transcending all distinctions (such as in Chapter 2) including utility and imatility.

To explain this paradox, Major proposes that the Zhuangzi is describing two forms of uselessness. What he calls "contingent uselessness" does not prechude having other useful qualities. One who embodies "contingent uselessness" remains somewhat involved in human affairs. The story of the goose in the beginning of Chapter 20 is an example. In

\footnotetext{
$n_{\text {Ibid, }} 137$.

n Ibid., 142.
} 
this story, a great tree is not cut down due to its uselessness. However, in the same story, a goose is killed due to its uselessness (i.e., it's inability to cackle). The goose's uselessness is contingent because of its involvement in the humban world. Consequently, its uselessness does not guarantee its survival. The tree, however, embodies "absolute uselessness" because it has no useful qualities at all. One who exhibits "absolute uselessness" renounces all human affairs. This and other examples of useless trees in the Inner Chapters exhibit the true ideal of the Zhuangzi. This kind of uselessness requires one to transcend the distinctions of the human world, to attain an enlightenment that is useful to the sage alone. ${ }^{00}$ Therefore, to attain enlightenment is to cultivate uselessness.

Wruwei, then, for Major, is not a way to solve problems (as it is for Fox), but a way of cultivating simplicity and conforming with the natural processes of the world. According to Major's view, one does not find a "fit" so much as an escape from harm. Wunel is a faculty of decision-making only insofar as the decision is to escape harm, not "solve a problem" (spontaneously or otherwise). ${ }^{\text {st }}$

This ideal of uselessness can be seen as the unidentified criterion of successful action for the above interpretations of ming. Contrary to Hansen, uselessness is a nonrelative ideal. It also points to a possible "cardinal dao" that Eno is searching for. The criterion for following any dao well is that it promotes uselessness/survival It also can be seen as a goal for Yearley's "transcendent drives" - the sign of the "ultimate spiritual state."

\footnotetext{
7 John S. Major, "The Efficacy of Uselessness: A Chung-tar Motif", Phllosophy East and West 25 (1976), 265.

10 Ibid, 275.

II Ibid.
} 
But this notion of survival seems to fly in the face of popular interpretations of Daoist views of death, that death is not something to be feared. Roger Ames, for example, notes that the Zhuangzi emphasizes a "continuity between and interdependence of life and death. ${ }^{\text {m2 }}$ Our problem is not death, but the unwarranted fear of death The Zhuangzi tells us that we have no reason to assume that life is better than death In the story of Lady $\mathrm{Li}$, for example, Lady $\mathrm{Li}$ is first upset that she is taken by a new lord and grieves for the life she must leave behind, only to realize that her new life is better than she ever could imagine. ${ }^{83}$ Likewise, we may discover that death is far better than life.

Ultimately, the Zhuangzi does not see death as an ending, but rather as a form of transformation (wu hua 物化). Under this view, death may bring new and exciting experiences. There are examples of people on their death beds who accept death as just another part of life, such that life is redefined as "life and death. ${ }^{\text {m4 }}$ They are but two parts of a single cycle, which is in constant motion from birth to death and over again. One should find contentment in the entire process itself, not in a mere part of the process.

It can be argued that this acceptance of death contradicts the emphasis on survival in other parts of the text, but reconciliation of these ideas requires an elaboration of Yearley's view of the ultimate spiritual state for the Zhuangzi. In particular, it requires showing how the "uselessness" of the Sage is not simply the "absolute uselessness" that Major ses as the Sage's key to survival. And the key to that project depends on an analysis of ming.

\footnotetext{
"Roger T. Ames, "Death as Transformation in Classical Deoism," in Death and Philosophy, eds. Jeff Malpes and Robert C. Solomon (New York: Routledge, 1998), 64.

${ }^{3}$ Ibid., 64-65., See Watson 42-43.

4 Ames, 65. Ames's main example in this regard is the story of Mester Lai, who falls ill and speaks of accepting death as transfarmation into a new form of life (eg, rat's liver, bug's leg). See Watson, 81-82.
} 
Contrary to Hansen, Ivanhoe, Fox, Cua, and Callahan, I interpret ming, not as a means to moral decision-making, but rather as a way to "dissolve" the moral debate between the Confucians and Mohists. What all these interpreters have neglected is the difference between the use of ming in the Zhuangzi and the use of ming in the Confucian and Mohist texts, which shows the Zhuangzi's use to be too different to be another moral concept. In these other texts, ming is the "clear" distinction between moral concepts and social roles, whereas ming in the Zhuangzi is the "illumination" of the unity of all distinctions.

The unity of distinctions is pre-linguistic; that is, even to talk about it is to, in a sense, lose touch with it. Therefore, the Zhuangzi is forced to "play" with language when it is not directly criticizing the views of the Confucians and Mohists. The Zhuangzi also cannot speak meaningfully about "good" and "evil" or "right" and "wrong" (ideas that are essential for any discussion of ethics), because to do so would contradict its own message about ming. Thus, the Sage is often described poetically, in order to remain consistent with the text's overall skepticism of the adequacy of language to describe reality. And this poeticism when describing the Sage suggests that the message of the Zhuangzi is more soteriological than moral.

This soteriological interpretation of ming in the Zhuangzi is strengthened by examining other ideas not discussed by Hansen, Ivanhoe, Fox, Cua, and Callahan, such as "uselessness" and "survival." Within a larger textusal context that includes these ideas, it is far more difficult to interpret the story of the cook in Chapter 3 as an example of moral dexterity. Instead, the cook can be seen to be one of many examples of ideal individuals (including useless trees and people impervious to harm) that exhibit a "spiritual" mastery. 
This spiritual mastery through ming is what ultimately reconciles the Sage as described by Yearley and Eno with both Major's discussion of survival through "uselessness" and Ames's discussion of death. Ming provides the ability of the Sage to transform or adapt to situations (similar to Fox's discussion of whwei without the moral context) and to "survive." But this ability to adapt comes through the personal transformation of the Sage, who renounces "survival" because it is simply one aspect of the cycle of life and death. Thus, the Sage actually lives longer by not "trying" to live longer; the Sage merely follows dao. 


\section{Chapter 1: Clarity in the Zhuanged}

[W] hat can be said at all can be said clearly, and what wo cannof talk about wo must pass over in silence. - Ludwig Wittgenstein ${ }^{\text {s }}$

"Precision and clarity" became a mantra of Anglo-American analytic philosophy, which, for the greater part of the twentieth century, confined itself to the issue of meaning in language. The argument was that anything worth philosophizing about could be explained in language, and whatever could not be explained clearly (as Wittgenstein noted) could not be the object of philosophical inquiry. Chinese philosophers, of course, were not analytic philosophers, but that did not prevent them from debating over their own philosophical problems, nor did it prevent them from valuing clarity. This chapter attempts to show that clarity (ming) was an important philosophical concept in early China, but the Zhuangzi has its own conception of what it is to use "clarity," which turns the views of the Confucians, Mohists, and even Wittgenstein on their heads.

As a philosophical concept, the term ming occurs fourteen times in the Inner Chapters of the Zhuangzi. ${ }^{26}$ The first instance occurs in the following passage in Chapter 2:

Words are not just wind. Words have something to say. But if what they have to say is not fixed, then do they really say something? People suppose that words are different from the peeps of beby birds, but is there any difference, or isn't there? What does the Way rely upon that we have true and false? What do words rely upon, that we have right and wrong? How can the Way go away and not exist? How can words exist and not be acceptable? When the Way relies on little accomplishments and words rely on vain show, then we have the rights and wrongs of the Confucians and Mohists. What one calls right

\footnotetext{
is Ludvig Witgenstein, Tractatus Logico-Philasophicus, trans. D.F. Pears and B.F. MoGuinness, (Now York: Routledges, 1974), 3.

26 This number does not include instances when ming is used as a proper noun or in phrases like ming $r i$ 明日 ("the next day" or "tomarrow").
} 
the other calls wrong; what one calls wrong the other calls right. But if we want to right their wrongs and wrong their rights, the best thing to use is elarity. (39)

This last statement about clarity should seem to offer a solution to the impasse between the Confucians and Mohists. The Zhuangzi insists that one should simply use clarity to solve theoretical conflicts as if it were that simple. But it is not simple, because the question begged by the Zhuangzi is "what is clarify?" Since the Confucians and Mohists also used the term ming, it will be fruitful to survey its use in the earty texts of those schools.

\section{Cisrity as Disecenment}

Analects 12.6 addresses the definition of ming as follows:

Zizhang asked about the meaning of the term "illumined" [ming]. The Master said, He who is influenced neither by the soaking in of glander nor by the assault of denunciation may indeed be called ilumined. He who is influenced neither by the soaking in of slander nor by the assault of denunciation may indeed be called "aloof" [ymon 港]

To say "illumingtion" is to be "aloof" is to say it is detachment (yuan) from the subjective whims of others. Conficius is simply endorsing the belief in a more objective standard than mere hearsay. One must be "aloof" enough to see this standand and not be blinded by

"All translations from the Zhuangzi are from Burton Watson, The Camplete Works of Chuang Tuu (New York: Columbia University Press, 1968). Numbers in parentheses refex to page numbers from this translation. Where necessary, I have converted Watuon's Wado-Giles transliteration to pinyin. Any boild hace is my own.

* Arthur Waley, trans, The Aralects of Conficius (Now York: Macmillan, 1938; reprint, New York: Vintage Books, 1989), 164 (page citution is to the reprint edition). The Analects is a composite text, and it is safe to say that none of it was written by Confucius himself In fact, scholars like Bruce and Tacko Brooks have made a point to date the different books of the Analects, which results (ecoonding to the Brooks) in a text that spens over two hundred years in the making. See their The Orighnal Analeets: Sayings of Confucius and His Successors (New York: Columbia University Press, 1998). Though some may take issue with some of the Brooks's theory, the issues of duting and authorship of the Analects cannot be ignored. As such, any refirence to what "Confixius" says in this thesis refers to the thought expressed in the Analects, but does not imply that I believe it was actusally uttered by the historical Confixius. 
falsehoods. An "aloof" or impartial standard is what gives one the power to discern truth from lies, good from evil, etc., and consequently to act accordingly. It is the hallmark of the junzi 君子 or "exemplary person," one who is not swayed even by desire for personal gain, and acts only from a senee of duty to others. This concern for others requires a sense of impartiality."

The Mozi also promotes a belief in impartiality. It sees clarity as understanding the standard of Heaven (tion 天). The Mozi states:

[I] f men do not do what Heaven desires, but instead do what Heaven does not desire, then Heaven will likewise not do what men desire, but instead will do what men don not desire. What is it that men do not desire? Sickness, misfortune, and disaster. Thus, if one does not do what Heaven desires, but instead does what Heaven does not desire, this is simply to lead to multitudes of the world in pursuing the path to misfortune and disaster.

Therefore the sage kings of antiquity sought to understand clearly [ming] what Heaven and the spirits would bless, and to avoid what Heaven and the spirits hate, and in this way they worked to promote what is beneficial to the world and eliminate what is harmfiul ${ }^{90}$

Clarity, then, as the adhering to the standard of Heaven, is a more reliable standard than subjective shander and denunciation. What is more, it determines one's fate. Clarity benefits the world with good fortune from Heaven; lack of clarity brings Heaven's vengeance. Thus it is crucial for the ruler to be able to discern what heaven favors and what it deplores. Clarity is an ability to "understand" morality as an acknowledgment of a higher power and that power's preferences."

\footnotetext{
Sec Analects 2.14

${ }^{90}$ Burton Watson, trans., Mo Tax: Baxic Writungs (New York: Columbia Univensity Press, 1963), 87.

91 Thongh the Mozd is also known for its "utilititarian" arguments for "universal love" (tian at sis a) and against music, it also reveals streng leanings towand a kind of "divine command theory" of morality, in which moral standards are simply the inventions of a higher power. Thus, the main criticisn of "divine command theory" (i.e, that it makes morality ultimately arbitrary and non-rational) also applies to this viow of clarity. It is Mencius (below) who avoids this setbeck by demonstrating how "clarity" in morality is more than following arbitrary rules of conduct. It recpires more rational doliberation.
} 
But some thought real clarity was more than just following the rules. The Mencius says in 4B.19:

The sage-king Shun was insightful [ming] about things. He was perceptive about human relationships. He acted out of benewolence and righteousness. He did not act out benevolence and righteousness. ${ }^{92}$

Shun embodied morality, rather than simply act in accordance with morality. This statement implies that ming is a sign of "authenticity" deeper than that expressed by the Mozi. While the Mozi wants us to follow the way of heaven, the Mencius wants us to internalize it as a constituent part of ourselves. It is not enough to simply perform the correct action. Clarity is also a state of mind, an intention, a sense of sincerity. It is discernment, but a kind of discernment that requires a certain amount of self-cultivation. For example, 4A.12 states:

There is a way for [a man] to become true to himself [cheng understand [ming] goodness he cannot be true to himself. Hence being true is the Way of Heaven; to reflect upon this is the Wry of man. There has never been a man totally true to himself who fails to move others. On the other hand, one who is not true to himself can never hope to move others. ${ }^{93}$

Here clarity (in the sense of "understanding") is explicitly linked to a sense of sincerity (cheng) through the discemment of "goodness." Mencius rationalizes morality by making it more than following simple guidelines; it requires a certain attitude and a certain amount of thought or "reflection" (si 思). It also produces the ability to influence other people in a positive way to make similar moral distinctions."

\footnotetext{
${ }^{22}$ Bryan W. Van Norden, trans, "Mengzi," in Readings in Classical Chtnese Phllosophy, eds. Philip J. Ivanhoe and Bryan W. Van Norden (New Yark: Seven Bridges Press, 2001), 136.

${ }_{93}$ D. C. Lau, trans., Mencius (New York: Penguin Books, 1970), 123.

"Compare Analects 2.1 .
} 
This sense of discernment is not alien to the Zhuangzi. The so-called "Syncretist" chapters also employ ming to mean knowing how to correctly distinguish moral categories. For example, Chapter 12 states:

Look [guan ri a d words in the light of the Way - then the sovereign of the world will be upright. Look at distinctions in the light of the Way - then the duty of sovereign and subject will be clear. Look at abilities in the light of the Way - then the officials of the world will be well ordered. Look everywhere in the light of the Way - then the response of the ten thousand things will be complete. (127)

Though ming only appears once in this passage, the "light" metaphor recurs indirectly through the term guan ("look"). The Way is what allows us to "see" things through words, distinctions, and abilities. All of these things help us to discern different parts of reality, which causes an ordering of society. This ordering in relation to ming is even more direct in a passage from Chapter 13:

If you speak of the Way and not of its sequence, then it is not a way; and if you speak of a way that is not a way, then how can amyone make his way by it? Therefore the men of ancient times who clearty understood the Great Way first made clear Heaven and then went on to the Way and its Virtue. Having made clear the Way and its Virtue, they went on to benevolence and righteousness. Having made clear benevolence and righteousness, they went on to the observance of duties. Having made clear observance of duties, they went on to forms and names. Having made elear forms and names, they went on to the assignment of suitable offices. Having made clear the assignment of suitable offices, they went on to the scrutiny of performance. Having made clear the scrutiny of performance, the went on to the judgement of right and wrong. Having made clear the judgement of right and wrong, they went on to rewards and punishments. Having made clear rewards and punishments, they could be certain that stupid and wise were in their proper place, that eminent and lowly were rightly ranked, that good and worthy men as well as unworthy ones showed their true form, that all duties suited to their abilities, that all acted in accordance with their titles. It was in this way that superiors were served, inferiors were shepherded, external things were ordered, the inner man was trained. (146-147)

Here, as in the Confucian and Mohist passages above, clarity is the root of morality. It allows one to grasp an accurate representation of a certain state of affairs, and 
subsequently initiate a "domino effect" of clarifications that result in an ordered society. This "domino effect" (or what the passage calls the "sequence" of the Way), which is a series of moral distinctions, is vital to understanding the Way. As in the passage from the Mencius, clarity is the root of the power to "move others" and thus order society.

The Confucian "ordering" of society is rooted in a series of distinctions, particularly social roles and ritual behavior specific to those roles. ${ }^{95}$ Without these distinctions, society would be leveled to a state of chaos. ${ }^{96}$ If clarity is to serve as an ordering device, it must "illumine" differences in moral concepts (i.e., "right" and "wrong") and social roles (i.e., "ruler," "minister," "husband," "wife," etc.). Thus, the dispute between the Confucians and Mohists is one of which distinctions to make, which activities are worthy of the designation of "right," which roles are to perform certain duties, and to whom are we most obligated (ie., "filial piety" vs, "universal love"). The Inner Chapters of the Zhuangzi, however, tell a different story.

\section{Clarity as Non-discernment}

The Inner Chapters treat distinctions as follows:

Everything has its "that," everything has its "this." From the point of view of "that" you cannot see it, but through understanding you can know it. So I say, "that" comes out of "this" and "this" depends on "that" - which is to say that "this" and "that" give birth to each other. But where there is birth there must be death; where there is death there must be birth. Where there is acceptability there must be unacceptability; where there is unacceptability there must be acceptability. Where there is recognition of right there must be recognition of wrong; where there is recognition of wrong there must be recognition of right. Therefore the sage does not proceed in such a way, but illuminates all in tho light of Heaven. He too recognizes $a$ "this," but a "this" which is also "that," a "that" which is also "this." His "that" has both a right and a wrong in it; his "this" too has both a right

\footnotetext{
${ }^{93}$ See for womple Menchus 3A,4 and Analects 12.11.

"See Analects 13.3.
} 
and a wrong in it. So, in fact, does he still have a "this" and a "that"? A state in which "this" and "that" no longer find their opposites is called the hinge of the Way. When the hinge is fitted into the socket, it can respond endlessly. Its right then is a single endlessness and its wrong too is a single endleseness. So I say the best thing to use is clarity. (34-35)

This passage also discusses distinctions and how they are created; namely, by postulating one thing or idea one automatically creates its opposite ("this" creates "that" and vice versa). But these distinctions are hardly valued the way they are by the Confucians, Mohists and Syncretists. The Inner Chapters of the Zhuangat depict perspectives and value judgments as relative, and hold that they arise from a more fundamental unity, daoshu or "hinge of the Way." As a result, one realizes that a "right" cannot exist without a "wrong" and "this" cannot exist without a "that" because each event is involved in a polar relationship with its respective opposite."

This polar relationship is exemplified in the famous "three in the morning" story about a monkey trainer and his monkeys:

When the monkey trainer was handing out acorns, he said, "You get three in the morning and four af night." This make all the monkeys furious. "Well, then," he said, "you get four in the morning and three at night." The monkeys were all delighted. There was no change in reality behind the words, and yet the monkeys responded with joy and anger. Let them, if they want to. So the sage harmonizes with both right and wrong and rests in Heaven the Equalizer. This is called walking two roads. (41)

The monkeys are ignorant of the fundamental unity of the set of acorns (i.e., that no matter how the set is divided, the number within the whole set remains constant). Likewise, according to the Zhuangzi, ordinary people are ignorant of the fundamental

"This notion of "polarity" is defined by Hall and Ames as "a relationship of two events each of which requires the other as a necessary condition for being what it is" in Mhthithg Through Confuctus (Albany. SUNY, 1987), 18. 
unity of all distinctions. But the Sage harmonizes these distinctions in the hinge of the Way by "illuminating" or "clarifying" them. No matter how one wishes to carve up reality, prior to the act of carving, reality (like the acorms) must be a united whole. In this sense, all possible "carvings" are equal insofar as there is "no change in reality behind the words."

Further on, the Zhuangzi shows how the Way was injured by the creation of right and wrong, and with the injury of the Way came creation of preferences. ${ }^{n}$ Three examples of those who mastered their preferences were Zhao Wen (the lute player), Music Master Kuang (who waved his baton), and Huizi (the logician). The Zhuangzi states:

Only in their likes they were different from him [the true sage]. What they liked, they tried to make elear. What he is not clear about, they tried to make clear, and so they ended in the foolishness of "hand" and "white." Their sons, too, devoted all their lives to their fathers' theories, but till their death never reached any completion. Can these men be said to have attained completion? If so, then so have all the rest of us. Or can they not be said to have attained completion? If so, then neither we nor anything else have attained it. The torch of chaos and doubt this is what the sage steers by. So he does not use things but relegates all to the constant. This is what it means to use charty. (42)

Here the Zhuongzi finally states what it means to use clarity, something far different than these three masters believed. These men, through developing their special talents became so obsessed with their particular abilities that they were blind to the original unity of things. They convinced themselves of a kind of false "enlightenment," but failed to recognize the fundamental unified whole within the Way. ${ }^{99}$ By contrast, when the sage

\footnotetext{
"The Chinese word at alterally means "love." Watson transhates this particular line literally as "and bectuse the W/ay was injured, love became complete" (41). I follow Victor Mair's interpretation of al in this case to mean "preferences": "What causes the diminution [of the Wey] is what leads to the ereation of preferencess" See his Wondering on the Way: Early Taotst Tales and Parables of Chuang Tzu (Honolutu: University of Hawaii Press, 1994), 17.

"Mair interprets the ming of these masters to meen "enlightenurent."
} 
acknowledges unity through the light of clarity, he is free of preferences and makes no distinctions.

The Zhuangzi even alludes to the discerning brand of clarity, which it quickly dismisses as flawed:

Yi Erzi said, "Yao told me, "You must learn to practice benevolence and righteousness and to speak clearty about right and wrong!" (89)

To this "Confucian" clarity, Xu You, the wise hermit, remariks that since Yi Erzi has been "tatooed" with benevolence and righteousness and has "had his nose cut off" with right and wrong, ${ }^{100}$ it is impossible for Yi Erzi to "go wandering in any far-away, carefree, asyou-ike-it paths." (89)

\section{Clarity and Silence}

Though the Zhroangzi advocates a kind of relativity of distinctions and perspectives, it still believes that one perspective - that of the Sage - is superior to all others so long as those other perspectives exchude each other (such as the perspectives of the Confucians and Mohists). This qualification of the Zhuangzi's relativism is important because it helps explain other passages of the text in which certain characters pass judgment on others for failing to see the equality and ultimate unity of all things, rather than simply acknowledging a different point of view. For example, in Chapter 5 there is a story of Shentu Jia (who had lost a foot), and Zichan (the prime minister of Zheng) studying under Bohun Wuren. Zichan criticizes Shentu Jia for acting as if he were equal to a prime minister, to which Shentu Jia replies:

${ }^{100}$ Watson remarks that these were common punishments (89). 
"Within the gates of the Master, is there any such thing as a prime minister? You take delight in being a prime minister and pushing people behind you. But I've heard that if the mirror is bright, no dust settles on it; if dust settles, it isn't really bright. When you live around worthy men a long time, you'll be free of faults. You regard the Master as a great man, and yet you talk like this - it's not right, is it?' (70)

Under a more conventional and simple relativism, Shentu Jia would have no reason to criticize Zichan, because both points of view would be would be "equal." But the use of ming (here translated as "bright") allows Shentu Jia to treat Zichan's remark as Zhuangzi does the polar opposite views of the Confucians and Mohists. Dust settling on the metaphorical mirror clouds the equality of all things - including that of the high-ranked and low-ranked people. Shentu Jia adds that their master, Bohun Wuren treats him no differently, despite the loss of his foot.

This qualified relativism also helps reconcile passages that favorably compare "great understanding" ( $d a$ zhi 大知) with "little understanding" (xiao zhi 小知). As the Zhuangzi says, "Great understanding is broad and unhurried; little understanding is cramped and busy" (37). The Zhuangzi is thus forced into an apparent paradox of favoring a perspective that relativizes all perspectives. But once it begins to describe what this perspective is, it fills into its own trap of making distinctions. To postulate the "unity" of opposites is to immediately create the notion of "plurality." But the text takes great pains to remind the reader of this very paradox. For example, when Zhang Wuzi says to Zhu Chuezi:

[T] he stupid believe they are awake, busily and brightly assuming they understand things, calling this man ruler, that one herdaman - bow densel Confucius and you are both dreaming! And when I say you are dreaming, I am dreaming too. Words like these will be labeled the Supreme Swindle. Yet; after ten thousand generations, a great sage may appear who will know their meaning, and it will still be as though he appeared with astonishing speed. (47-48) 
Zhang Wuzi has to admit the he is also dreaming because he is doing precisely that which he criticizes Confucius and others for doing - clinging to distinctions. To say someone is "dreaming" is to create the idea of "not dreaming" or "awake." He has to somehow bracket his speech as a kind of "metalanguage" to point out the limits of language's ability to capture reality. In realizing this predicament, the text resorts to "playing" with language to show how language as a tool of discermment is always a step off the "hinge of dao." Like Zhang Wuzi it adds a disclaimer to itself when it says, "Now I have just said something. But I don't know whether what I have said bas really said something or whether it hasn't said something." (43)

The first anecdote of Chapter 22, though it was written later than the Imner Chapters, explains the relationship between knowlodge (and thus, "clarity") and language that is also found in the Inner Chapters. In this story, the character, Knowledge, wanders around asking people about dao. The first person Knowledge asks not only does not respond, but does not know how to respond. The second person Knowledge asks tries to respond but suddenly forgets what to say. Finally, Knowledge asks the Yellow Emperor, who pontificates in the enigmatic language so characteristic of Daoist texts:

Only when there is no pondering and no cogitation will you get to know the Way. Only when you have no surroundings and follow no practices will you find rest in the Way. Only when there is no path and no procedure can you get to the Way. (234-235)

In saying there is no "path" (i.e., "way") to get to the Way, the Yellow Emperor is attempting to explain what cannot be explained. True knowledge is not the intellectual discernment of the Confucians and Mohists. But Knowledge (the character) makes the 
mistake of clinging to the words of the Yellow Emperor as an explanation of dao. The Yellow Emperor is then forced to explain that of the three people Knowledge asked, he is himself the farthest from the truth, beceuse the person closest to the truth is the one who does not answer at all. It is this person who has remained on the hinge of dao, whereas the Yellow Emperor slips into the very dispute of the Confucians and Mohists that he would tike to avoid. Thus, in attempting to verbalize dao, he is forced to point to it by first stepping off of it, and then referring back to it through discerning language. He rejects the discerning light metaphor of the Confucians and Mohists when he says:

The Way cannot be brought to light; its virtue cannot be forced to come. But benevolence - you can put that into practice; you can discourse on righteousness, you can dupe one another with rites. So it is said, When the Way was lost, then there was virtue; when virtue was lost, then there was righteousness; when righteousness was lost, then there were rites. Rites are the frills of the Way and the forerunners of disorder. (235)

This process is a complete reversal of what is implied in the Mencius and made explicit in the Syncretist Chapters. The process of discerning clarification is what creates disonder rather than order. The concepts of "benevolence" and "righteousness" actually "blind" the individual rather than "clarify" or "illumine."

For this reason, the Yellow Emperor echoes Chapter 56 of the Laozi by saying, "Those who know do not speak; those who speak do not know" and concludes that the Sage practices the teaching that has no words. But he also says:

He who practices the Way does less every day, does less and goes on doing less, until he reaches the point where he does nothing, does nothing and yet there is nothing that is not done. (235)

This idea of "non-action" ( $w u$ wei) is what links the Zhuangzi's conception on clarity to the Sage's behavior. 
The link between clarity and non-action is most explicit in Chapter 7 when Yangri

\section{Zhu visits Lao Dan:}

Yangzi Zhu went to see Lao Dan and said, "Here is a man swift as an echo, strong as a beam, with a wonderfully clear understanding of the principles of things, studying the Way without ever letting up - a man like this could compare with an enlightened king, couldn't he?"

Lao Dan said, "In comparison to the sage, a man like this is a drudging slave, a craftsman bound to his calling, wearing out his body, grieving his mind. They say it is the beautifil markings of the tiger and the leopard that call out the hunters, the nimbleness of the monkey and the ability of the dog to catch rats that make them end up chained. A man like this - how could he compare to an enlightened king?"

Yangzi Zhu, much taken aback, said, "May I venture to ask about the government of the enlightened king?"

Lao Dan said, "The government of the enlightened king? His achievements blanket the world but appear not to be his own doing. His transforming influence touches the ten thousand things but the people do not depend on him. With him there is no promotion or praise - he lets everything find its own enjoyment. He takes his stand on what camnot be fathomed and wanders where there is nothing at all." (94)

Lao Dan indulges in the same kind of mystical explanation as the Yellow Emperor,

but the difference between his conception of ming and the Confucian/Mohist conception is evident. According to Lao Dan, the "enlightened king" scoffs at the notion of "clarifying" principles if it means, as discussed above, that one speaks "clearly" of right and wrong in a sense they are completely separate from each other. What makes the king "enlightened" is his acceptance of all things in letting "everything find its own enjoyment," which implies that the king really does not "govern" at all, at least not in the sense outlined by the Confucian, Mohists (or even the Syncretists). Their sense of governing requires distinctions to be made between social roles and modes of behavior that create a plurality of names to create order. But as in Chapter 22, the Zhuangal implies that order is not something to be created or imposed. It is something that is already there without the 
intrusive and artificial distinctions of the Confucians and Mohists. It is something "clear" to an "enlightened king" or the Sage.

\section{Silence and Soteriology}

The Yellow Emperor and Lao Dan also show the Zhuangzi focussing on a much different area of inquiry than morality and politics. The Yellow Emperor states that the Sage "does nothing and yet there is nothing left undone," and Lao Dan states that the Sage "takes his stand on what cannot be fathomed and wanders where there is nothing at all." These statements can hardly be fathomed as moral prescriptions, especially in light of text's previous discussion of ming. Since clarity as non-discernment results in ultimate silence, the Zhuangzi cannot make moral prescriptions in the ways of the Confiucians and Mohists. Moral discourse as discourse depends on language and discernment. Without some discernment between ideas such as good and evil, acceptable and unacceptable, the very notion of ethics or morality is virtually meaningless. Even if one's moral theory relies on the particular context of the action rather than absolute principles, the ideas of "right" and "wrong" still must be relevant in the particular context. ${ }^{101}$

The descriptions of the ideal individual in the Zhuangzi rarely, if ever, exalt moral qualities. Instead, like the descriptions from the Yellow Emperor and Lao Dan, they paint a poetic picture of extraordinary individuals. The classic descriptions of the Zhuangzi's ideal individual occur in Chapter 6 where this individual is identified as zhenren 点人一 "True Man" or "True Person":

\footnotetext{
${ }^{101}$ This contextualist morality is not alien to the Zhuongze's philosophical adversaries. See for example Mencius 4A.17.
} 
rather than absolute principles, the ideas of "right" and "wrong" still must be relevant in the particular context. ${ }^{101}$

The descriptions of the ideal individual in the Zhuangzi rarely, if ever, exalt moral qualities. Instead, like the descriptions from the Yellow Emperor and Lao Dan, they paint a poetic picture of extraordinary individuals. The classic descriptions of the Zhuangzi's ideal individual occur in Chapter 6 where this individual is identified as zhenren 1 人 - “True Man" or "True Person":

A man like this could climb the high places and not be frightened, could enter the water and not get wet, could enter the fire and not get burned. His knowledge was able to climb all the way up to the Way like this. (77)

While courage in high places is not an unreasonable virtue, repelling water and heat are fantastic qualities. Surely the Zhuangzi does not expect the reader to take such descriptions literally, nor is it clear how these qualities demonstrate any kind of moral perfection. ${ }^{102}$ It is far more likely that these are metaphorical descriptions of a soteriological experience of the zhenren. Through this soteriological experience, the zhenren cultivates an inner transformation of a more "spiritual" nature rather than a moral nature. ${ }^{103}$ The Zhuongzi thus shifts its focus away from the morality and politics (the predominant concerns of the Confucians and Mohists) and into new territory largely ignored by the other traditions. Ming is not moral discernment, but rather a kind of spiritual "enlightenment," which begins with the "liberation" from Confucian and Mohist

\footnotetext{
${ }^{101}$ This contextualist morality is not aliea to the Zhuongza's philosophical adversaries. See for example Mencius 4 A. 17.

${ }_{102}$ Compare this description of the zhemren with the more concrete descriptions of the junat in the Analects, especially those which contrast the fund with the xiconen. One will notice the jwori described with specific moral attributes.

${ }^{103}$ I am using "soteriology" is a brosder sense then the traditionsal theological sense of "salvation theory." As discussed below, I believe the "tiberation" from Confician and Mohist dualities can be described as a form of soteriology for the Zhuangzi.
} 
dualistic concepts that can only be described as an experience of mystical, ineffable unity - any description of which must be qualified by playful "deconstruction," and the person who experiences such unity is flowered in poetic metaphors. The only other option is silence.

\section{Summary and Conclusion}

Though the concept of ming is not unique to the Zhruangzi, the Zhuangzi's use of ming is. The Confucian and Mohist texts use ming as way to discern and discriminate between moral/political categories. By contrast, the Zhuangzi uses ming as a form of non-discernment of categories and the realization of the fundamental and pre-linguistic unity of opposites. The result of this realization is shift away morality and toward soteriology. The Sage is not a moral exemplar, but rather a symbol of spirituality, the description of which can only be discussed in poetic metaphors. No further clarity (in Wittegstein's sense) can be attained, and thus, like Knowledge's first acquaintance in Chapter 22, we must pass over in silence. But for the Zhuangzi, to pass over in silence is precisely what clarity (ming) is.

Fortunately, however, the Zhuangzi is not silent, and not all descriptions of the ideal person are marked by such extreme poeticism. There are many other stories that provide the reader with more "down to earth" examples of what this ideal person is like, several of which portray people with miraculous skill, agility, and most of all, longevity. The Zhuangzi's emphasis on longevity or survival in conjunction with the idea of "uselessness" distances the text from the Confucians and Mohists and ultimately fleshes out the Zhuangzi's view of spiritual transformation. 


\section{Chapter 2: Longevity and Transformation in the Zhuangz'}

By far the most frequently discussed story of the ideal individual in the Zhuangzi

is the one about a lowly cook who can effortlessly carve up an ox without dulling his

blade one bit in Chapter 3. After receiving praise for his miraculous skill, the cook

replies:

What I care about is the Way, which goes beyond skill. When I first began cutting up oxen, all I could see was the ox itself. After three years I no longer saw the whole ox. And now - now I go at it by spirit and don't look with my eyes. Perception and understanding have come to a stop and spirit moves where it wants. I go along with the natural makeup, strike in the big hollows, guide the knife through the big openings, and follow thing as they are. So I never touch the smallest ligament or tendon, much less a main joint. (51)

It is easy to interpret this story more as a description of moral action than as an illustration of spiritual mastery. Here the Zhuangzi appears to begin describing a kind of normative "theory" of decision making. It sounds much like Aristotle's habituation of the virtues, in the sense that after a certain period of time, the cook needs little thought in how he acts. He reaches a state where acting appropriately is almost second-nature, knowing the single best way to act in a given situation. But as the cook continues his explanation, he elaborates on the ox/moral situation as follows:

There are spaces between the joints, and the blade of the knife has really no thickness. If you insert what has no thickness into such spaces, then there's plenty of room - more than enough for the blade to play about it. That's why after nineteen years the blade of my knife is still as good as when it first cam from the grindstone. (51)

As the blade finds room to "play about," the Zhuangzi reveals what appears to be a more complicated contextualist morality than discussed above (i.e., a morality where contexts 
offer more than one option). But it is important to notice what the cook says right before these lines:

A good cook changes his knife once a year - because he cuts. A mediocre cook changes his knife once a month - because he hacks. I've had this knife of mine for nineteen years and I've cut up thousands of oxen with it, and yet the blade is as good as though it had just come from the grindstone. (51)

The ability of the each cook is measured by the longevity (or survival) of the knife. The acts of cutting and hacking (i.e., making artificial distinctions) necessarily damage the blade of the knife. This cook, by contrast, preserves the "life" of his knife by not trying to alter the natural order of the ox but follow it to successfully carve along the natural openings. Consequently, the cook's knife "survives" for over nineteen years. If we link this story to the discussions of ming in other parts of the text, it is possible to interpret this story not to mean that the cook has discovered clarity of right action, but that he (or his knife) escapes or evades the artificial distinction of right and wrong and thereby keeps his knife intact. The cook moves beyond skill (and, for that matter, beyond morality) to slice through the space between the joints of the ox. In a similar manner, the Zhuangzi seeks to slice through the spaces between the disputes of the Confucians and Mohists, not by offering a new theory of "right" and "wrong," but rather by bypassing conventional morality altogether. In the light of clarity, the Sage sees the unity of the Confucian and Mohist perspectives and therefore can live a long life. This value of survival is pointed out also in the first section of Chapter 3 , just before the beginning of the cook's story:

Follow the middle; go by what is constant, and you can stay in one piece, keep yourself alive, look after your parents, and live out your years. (50) 
And again at the end of the story, Lord Wenhui remarks: "I have heard the words of Cook Ding and learned how to care for life!" (51).

Caring for life is central to the Zhuangzi. It requires a form of inquiry that moves beyond morality into the more existential aspect of life, namely, the inevitability of death. Analects 11.12 says that Confucius was unwilling to explain death to his disciple because his disciple did not yet understand life. This passage is often quoted to demonstrate Confucius's emphasis on matters of the "here-and-now," rather than of the supernatural or the afterlife. The Zhuangzi's treatment of death, however, appears to be the converse of Confucius: one cannot understand life unless one understands death. But understanding the Zhuangzi's view of death requires reconciling an apparent contradiction in the text, which not only entails reconciling embracing death with striving for longevity, but also the "skill" of this cook and the "uselessness" of other characters.

\section{Death and Longevity}

The Zhuangzi frequently argues that death is not something to be feared. For all we know, it may even be better than life:

Lady $\mathrm{Li}$ was the daughter of the border guard of $\mathrm{Ai}$. When she was taken captive and brought to the state of Jin, she wept until her tears drenched the collar of her robe. But later, when she went to live in the palace of the ruler, shared his couch with him, and ate the delicious meats of his table, she wondered why she had ever wept. How do I know that the dead do not wonder why they ever longed for life. (47) 
Such speculations are meant to shake us from our ordinary fear of death and eventually accept the correlative connection between life and death as a single process of transformation (wu hua):

Suddenly Master Lai grew ill. Gasping and wheezing, he lay at the point of death. His wife and children gathered round in a circle and began to cry. Master Li, who had come to ask how he was, said, "Shoo! Get back! Don't disturb the process of change!"

Then he leaned against the doorway and talked to Master Lai. "How marvelous the Creator is! What is he going to make out of you next? Where is he going to send you? Will he make you into a rat's liver? Will he make you into a bug's arm?"

Master Lai said, "A child, obeying his father and mother, goes wherever he is told, east or west, south or north. And the yin and yang - how much more are they to a man than father or mother! Now that they havo brought me to the verge of death, if I should refuse to obey them, how perverse I would be! What fault is it of theirs? The Great Clod burdens me with form, labors me with life, eases me with old age, and rests me in death. So if I think well of my life, for the same reason I must think well of my death. ... Where could [the Creator] send me that would not be all right? I will go off to sleep peacefully, and then with a start I will wake up." (85)

And in another well-known passage:

Zhuangzi's wife died. When Huizi went to convey his condolences, he found Zhuangzi sitting with his legs sprawled out, pounding on a tub and singing. "You lived with her, she brought up your children and grew old" said Huizi. "It should be enough simply not to weep at her death. But pounding on a tub and singing this is going too far, isn't it? Zhuangzi said, "You're wrong. When she first died, do you think I didn't grieve like anyone else? But I looked back to her beginning and the time before she was born. Not only the time before she was borm, but the time before she had body. Not only the time before she had a body, but the time before she had a spirit. In the midst of the jumble of wonder and mystery a change took place and she had a spirit. Another change and she had a body. Another change and she was born. Now there's been another change and she's dead. It's just like the progression of the four seasons, spring, summer, fall, winter.

"Now she's going to lie peacefully in a vast room. If I were to follow after her bawling and sobbing, it would show that I don't understand anything about fate. So I stopped." (191-192) 
Both of these passages are frequently cited to demonstrate the Zhuuangzi's acceptance of death as a transforming process. Death is not something to be feared, but rather, to be embraced. Even conceptually, one must accept death: ". . . where there is birth, there must be death; where there is death, there must be birth" (39).

But there are many passages in the Zhuangzi (such as the story of the cook in Chapter 3) that appear inconsistent with this view. At many points in the Inner Chapters, there are passages that praise longevity, or at least warn against the danger of death. Much of the Zhucangzi s arguments against government service, for example, rest on the assertion that such participation in the government will result in an early death. The first example of this view comes at the end of the first chapter in Zhuangzi's discussion with Huizi about Huizi's "useless" tree. Zhuangzi's final retort to Huizi is that the tree's "uselessness" (wu yong 管用)is actually quite useful in the sense that "uselessness" keeps it alive: "Axes will never shorten it's life, nothing can ever harm it. If there is no use for it, how can it come to grief or pain?" (35)

Another useless tree story appears in Chapter 4, where Carpenter Shi condemns a tree shrine for having useless wood. The tree then appears to the carpenter in a dream and proudly flaunts its uselessness as the reason it has been able to survive for so long. When Carpenter Shi awakens, he tells his apprentice that the tree cannot be understood through "conventional standards." (65)

The Zhuangzi's "unconventional" value of longevity is most forcefully asserted at the end of Chapter 4 by Jie Yu, the madman of Chu, who sternly criticizes Confucius:

Phoenix, phoenix, how has virtue failed! The future you cannot wait for; the past you cannot pursue. When the world has the Way, the sage succeeds; when the world is without the Way, the sage survives. In times like the present, we do well 
to escape penalty. Good fortune is light as a feather, but nobody know how to hold it up. Misfortume is heavy as the earth, but nobody knows how to stay out of its way. Leave off, leave off - this teaching men virtue! Dangerous, dangerous to mark off the ground and run! Fool, fool - don't spoil my walking! I walk a crooked way - don't step on my feet. The mountain trees do themselves harm; the grease in the torch burns itself up. The cinnamon can be eaten and so it gets cut down; the lacquer tree can be used so it gets hacked apart. All men know the use of the useful, but nobody knows the use of the useless! (66-67)

\section{Death and Martyrdom}

The coupling of death and public service, is not unique to the Zhuangzi. It appears in other early Chinese texts, though it often appears in a moral context. The Mozi, for example, says:

Now what does Heaven desire and what does it hate? Heaven desires righteousness and hates unrighteousness. ... If I do not do what Heaven desires and instead do what Heaven does not desire, then I will be leading the people of the world to devote themselves to what will bring misfortune and calamity. How do I know that Heaven desires righteousness and hates unrighteousness? In the world, where there is righteousness there is life; where there is unrighteousness there is death. ${ }^{104}$

Though Confucius does not care to speak of an afterlife, he does mention in Analects

6.19 how a life devoid of virtue could be short one:

That a person lives is because that person is straight. That a person who dupes others survives is because that person has been fortunate enough to be spared. ${ }^{105}$

Likewise, Mencius notes in 4A.9:

If one does not aim steadfastly at ren, one will suffer worry and disgrace all one's life and end in the snare of death ${ }^{106}$

\footnotetext{
${ }^{104}$ Wateon, Mo Tan, 79.

${ }^{105}$ D. C. Lall, trans., The Analects (New York: Penguin, 1979), 84. I have llightly modified Lau's transiation of this passage.

${ }^{106}$ Lau, Mencius, 122.
} 
And again in 4A.3:

... a gentleman or a commoner cannot preserve his four limbs unless he has ren. To dislike death yet revel in cruelty is no different from drinking beyond your capacity despite your dislike for drunkenness. ${ }^{107}$

Mozi fears offending Heaven, which shows his affinity to traditional religious beliefs.

But for the Confucians, especially Mencius, a ruler's loss of virtue and subsequent loss

life is explained through a more secular morality:

King Xuan of Chi asked, "Is it true that Tang banished Jie and King Wu marched against Zhou?"

"It is so recorded," answered Mencius.

"Is regicide permissible?"

"A person who mutilates ren is a mutilator, while one who cripple rightness is a crippler. One who is both a mutilator and a crippler is an 'outcast.' I have indeed heard of the punishment of the 'outcast Zhou,' but I have not heard of any regicide. ${ }^{\text {nos }}$

The ruler can expect such a violent reaction to an immoral government. Though

Zhou's lack of virtue prevented him from being labeled a king, someone named Zhou

was killed. ${ }^{109}$ Here is a case in which immorality results in death. But just because

someone is killed does not mean the person was immoral. Advisors to the king may lose

their lives in standing up for morality. Confucius says in Analects 15.9;

For the gentleman of purpose and people of ren while it is inconceivable that they should seek to stay alive at the expense of ren, it may happen that they have to accept death in order to have ren accomplished. ${ }^{110}$

Mencius echoes this point in 6A.10:

${ }^{107}$ Ibid., 119 (modified).

${ }_{108}^{108}$ Menchus 1B.8. Ibid., 68 (modified).

${ }^{109}$ In classical Conficcianism the terms "ling" "father," etc., do not simply denote peopto who perform these roles, but rather people who perform them well. "King," for Mencius implies "good (moral) king."

${ }^{110}$ Lan, The Analects, 133 (modified). 
Life is what I want; dutifulness is also what I want. If I cannot have both, I would rather take dutifulness than life. On the one hand, though life is what I want, there is something I want more than life. That is why I do not cling to life at all costs. On the other hand, though death is what I loathe, there is something I loathe more than death. That is why there are troubles I do not avoid. ${ }^{11}$

Though Confucian morality may serve to lengthen one's life, longevity is not the criterion for morality, and life may even be sacrificed for the sake of a good cause. Thus, one can be a martyr in Confucian ethics.

In the Zhroangzi, however, martyrdom is never advocated. In fact, the Zhuangzi often recommends the avoidance of any behavior that may result in one's execution. In Chapter 4, for example, Confucius (mouthing the Zhuangzi's ideas) counsels Yan Hui, who plans to advise the incompetent ruler of Wei. Yan Hui advances several methods of advisement, but Confucius rejects all of them. Each of Yan Hui's methods, according to Confucius, will at best cease to convert the ruler, or at worst end in Yan Hui's execution. Though Yan Hui appears to be a model of ren, the threat of execution is enough for Confucius to reject such methods. When Yan Hui finally asks for Confucius's advice.

Confucius tells him to "fast his mind." In his explanation Confucius says:

Make your will onel Don't listen with your ears, listen with your mind. No, don't listen with your mind, but listen with your spirit. Listening stops with the ears, the mind stops with recognition, but spirit is empty and waits on all things. The Way gathers in emptiness alone. Emptiness is the fasting of the mind (5758)

In subsequent passages, similar mystical advice is given to potential advisors to two other rulers. These men present Confucius with traditional "Confucian" methods of advising the rulers, but Confucius rejects each method in preference for a more passive approach. He says to Yan He:

${ }^{111}$ Lan, Mencius, 166. 
Don't you know how the tiger trainer goes about it? He doesn't dare give the tiger any living thing to eat for fear it will learn the taste of fury by killing it. He doesn't dare give it any whole thing to eat for fear it will learn the taste of fury by tearing it apart. He gauges the state of the tiger's appetite and thoroughly understands its fierce disposition. Tigers are a different breed from men, and yet you can train them to be gentle with their keepers by following along with them. The men who get killed are the ones who go against them. (63)

In each case, Confucius's advice is not to give advice to the ruler, especially if it might lead to death. One must passively follow the lead of the ruler, and adjust oneself to the ruler's needs.

\section{Reconciling Death and Longevity}

But why should it matter if one dies an early death? After all, the Zhuangzi says "the [zhenren] of ancient times knew nothing of loving life, knew nothing of hating death" (78), and the Sage "delights in early death" as much as in old age (81). If this is the case, could not these wandering advisors do as they pleased (i.e., frankly advise the rulers they encountered), despite the dangers?

It does appear that there are two irreconcilable goals proposed in the text, perhaps even two "daoisms." H.G. Creel suggested classifying the passages endorsing longevity as "purposive" and the passages that make light of death as "contemplative." Creel did not have a problem with the confliet, since "the fact that two views are logically incompatible seldom prevents people from holding them simultaneously. ${ }^{n 113}$ While this

\footnotetext{
${ }^{112}$ Herlee G. Creel, "On Two Aspects of Earty Taciam," in Whar is Tooism?, (Chicago: Chicago Univerity Press, 1970), 37-47. Creel insisted (paxe Maspero) that "contemplative" Daoism it more dominamt than "purposive" Dacism, especially in the Zhuangz. For the purpose of this paper, whether Creel is correct, or oven whether his original distinction is accurate, does not concern mo. I do show, however, that the distinction is unnecessary in reconciling this apparent conflict within the text.

${ }^{113}$ Creel, 45 .
} 
may be a possibility, I think there is at least one alternative that reconciles the value of longevity and the contemplative acceptance of death

If we return to Confucius's advice to Yan Hui, we notice that his suggestion to "fast the mind" is a practice for Yan Hui to master in himself. It is not enough for Yan Hui to merely acknowledge intellectually that life and death are connected in the "transformation of things." It is the fasting of the mind that creates a more "intuitive" understanding within him. Without this intuitive understanding, Yan Hui would most likely think like Mencius: willing to sacrifice his life for the sake of duty. But Confucius says that "fasting the mind" amounts to achieving some sort of "emptiness." Elsewhere, the Zhuangzi says:

Be empty, that is all. The Perfect Man uses his mind like a mirror - going after nothing, welcoming nothing, responding but not storing. Therefore he can win out over things and not hurt himself. (97)

The Zhuangzi's ideal person, then, attains longevity, but it amounts to a kind of byproduct of transcending the desire for longevity. The "Perfect Man" goes after and welcomes nothing, and that must include longevity. In the end, longevity is attained when one stops wanting it. Carpenter Shi and the three men counseled by Confucius see value in the useless tree and Confucius's advice because both the tree and Confucius hold the secret to longevity. Ironically, however, the state of awareness that would place value on longevity must eventually be transformed to a higher state of "illumination" (ming), which sees the ultimate unity of distinctions - including the distinction between life and death As discussed in the previous chapter, the Zhrangzi speaks of this unity of distinctions as the "hinge of the Way" (dooshu). But this state in dooshu is not a completely inactive one. The Zhruangzi says, "When the hinge is fitted into the socket, it 
can respond (ying 應) endlessly" (40), just as the "minror mind" responds without holding on to the "reflection."

\section{Uselessness and Skillfulness}

This mirror metaphor, through the attribute of "responding but not storing," serves to further clarify "uselessness" in the Zhuangzi. It would be wrong to assume that "uselessness" is either not acting at all, or trying to remain "useless" the same way at all times. The story of the goose in Chapter 20, though it is not part of the Inner Chapters, qualifies "uselessness" in a way that supports an idea I believe is also in the Inner Chapters. In this story, Zhuangzi is walking in mountains and notices a tree passed over by a woodcutter due to its "worthlessness" (bu neng 不能), and Zhuangzi remarks that the tree's "worthlessness" allowed it to enjoy a long life. When Zhuangzi comes down the mountain, he stops for the night at a friend's house. The friend then orders that a goose be killed and prepared for the occasion. The host's son asks which of two geese should be killed: the one that can cackle, or the one that cannot. The host tells his son to kill the one that cannot cackle. The next day, Zhuangzi's disciples ask him:

Yesterday there was a tree on the mountain that gets to live out the years Heaven gave it because of its worthlessness. Now there's our host's goose that gets killed because of its worthlessness. What position would you take in such a case Master? (209)

Zhuangzi laughs and responds:

I'd probably take a position halfway between worth and worthlessness. But halfway between worthlessness, though it might seem to be a good place, really isn't - you'll never get away from trouble there. It would be very different, though if you were to climb upon the Way and its Virtue and go drifting and wandering, neither praised nor damned, now a dragon, now a snake, shifting with the times, never willing to hold on to one course only. Now up, now down, taking 
harmony for your measure, drifting and wandering with the ancestor of ten thousand things, treating things as things but not letting them treat you as a thing - then how could you get into any trouble? (209-210)

The Zhuangzi does not contradict or retract the idea of "uselessness" (or "worthlessness") here, but rather elaborates on what true "uselessness" entails. As discussed in the introduction, John Major tries to reconcile this story with the "uselessness" stories of the Inner Chapters by making a distinction between two types of "uselessness": "contingent uselessness" and "absolute uselessness." "Contingent uselessness" retains some useful qualities, whereas "absolute uselessness" is the complete absence of any useful qualities to anyone other than oneself. ${ }^{114}$ The goose embodies "contingent uselessness," and consequently gets killed. The tree, however, embodies "absolute uselessness" and survives.

But I believe "absolute uselessness" needs to be qualified a bit to fit what Zhuangzi says to his disciples. Zhuangzi stresses that "uselessness" "worthlessness" is not any one thing or one state of being. The "uselessness" that ensures one's survival at one moment may not be what ensures it the next. One must follow dao in any number of directions and in any number of situations. The "worthlessness" of the tree in Chapter 20 may save it from Warring States woodcutters, but will this same "worthlessness" save it from twentieth century urban developers?

The goose's mistake is not simply that it has useful qualities, but rather that it does not transform (i.e., adapt) itself to new situations. The tree in Chapter 4 actually serves as the best example of "uselessness." Though it is useless to Carpenter Shi, it is

\footnotetext{
${ }^{114}$ Major, 272.
} 
quite useful to the villagers who treat it as a shrine. But even this tree may have to transform in such a way as to avoid other dangers at other times.

To be successfully "useless" one must be like the cook's knife in Chapter 3, which lasts over nineteen years (as opposed to those of other cooks that have to be changed frequently). The cook of Chapter 3 has no single way of cutting. He is praised for his skill, but he insists that he merely follows dao, which is beyond skill. His "perception and understanding. . . come to a stop" (51). In other words, he ceases to depend on the discerning form of clarity cherished by the Confucians and Mohists. But the result, of course, is not inaction; the cook successfully carves the ox. The difference in the cook's action, as opposed to the action of a good Confucian or Mohist, is that the cook never goes against the makeup of the ox for the sake of morality. The cook simply follows "things as they are." To not "follow things as they are" and follow one single way of cutting (or living), is to not attain the kind of "clarity" or "illumination" (ming) required for longevity. One may end up like the goose that did not cackle or the Confucian who would not sacrifice ren 仁 - dead.

But again, the longevity of the blade is dependent upon the transformation of the way the cook thinks. "Usefulness" and "uselessness," like "right" and "wrong" and "life" and "death," and even "skill" and the "lack of skill," are distinctions that are transcended through the transformation of things in dao through the "illumination" of ming. The skilled cook and the useless tree both must attain the consciousness of Master Lai, who sees his transformation from life to death as nothing to be feared.

Master Lai, of course, is not immortal, and neither (I presume) are any of the "useless" or "skillful" characters in the text. Despite their longevity, they, like Master 
Lai, will eventually die; but the Zhuangzi implies that their deaths will come as a natural transformation rather than an "unnatural" execution.

Thus, longevity and transformation are not irreconcilable views in the Zhuangzi. Longevity entails transformation. "Uselessness" is not simply avoiding harm. To avoid harm requires a certain agility found only in the more "illumined" state of the Sage, a state in which one can transform according to dao. Able to adapt to various kinds of "uselessness," the Sage maintains longevity, but is not necessarily conscious that s/he is doing so. One's transformation within "illumination" ensures longevity, and to be ensured longevity is to see death as simply part of a larger transformation. 


\section{Conclusion}

Nothing in the Zhuangzi is simple or direct. The text is at once both philosophically challenging and aesthetically mesmerizing, and each of these aspects is inextricably enmeshed with the other. Such is the case when philosophy comes in the form of parables rather than propositions. One temptation is to "reconstruct" the Zhuangzi into systematic philosophy, to reduce parables to propositions, and thus "discover" the Zhruangzi"s "real argument." Another temptation is to dismiss the Zhuangzi as esoteric mysticism that is philosophically impenetrable, as if the text is too "deep" for philosophical analysis. Both these temptations must be resisted if the we are to fully comprehend the meaning(s) of the Zhuangzi.

The notions of "clarity" and "survival" in the Zhuangzi are rooted in mysticism. They require the individual to achieve an altered state of consciousness or, at the very least, an new disposition. Descriptions of individuals who achieve this altered state or new disposition cannot be described directly, because their actions cannot be limited to particular rules or principles (as opposed to the ideal individuals for the Confucians and Mohists). The Sage is supposed to have discovered the fundamental unity of all distinctions and thus must embrace them all. To say that the Sage is "this" or "that" would contradict the kind of knowledge the Sage is said to acquire. Therefore the Zhuangzi resorts to its delightful (or for some, frustrating) paradoxes and fantastic metaphors.

But the Zhuangzi's mysticism is not irrational. The text also supports many of its claims with argumentation. Several passages in which Zhuangzi debates Huizi quickly 
dispel any suspicion of the text's argumentative ineptness. The bulk of Chapter 2 , in which the Zhuangzi harshly criticizes the Confucians and Mohists, is also a sign of the Zhucangzi's talent for sustained argumentation (which is probably why scholars discussed it more than any other chapter in the text). The Zhuangzi is strongly critical of language's ability to grasp reality, but it is also highly skilled in using language to get its point across, even if it resorts to apparent contradictions.

For the Zhuangzi, understanding both clarity and survival requires embracing apparent contradictions. The very essence of clarity is in the unity of correlative opposites, and survival comes from renouncing the desire for survival altogether. But in the end, both situations are only paradoxical to the "unenlightened," those who do not "use clarity," those without the dao.

Like all other early Chinese philosophical texts, dao is the focus of the Zhuangzi. But unlike the dao of the Confucians and Mohists, the Zhuangzi's dao is not a system of morality. Dao serves a soteriological function, not a moral one. It provides a kind of "spiritual illumination," not "moral clarity." As such, the Zhuangzi takes disputation only so far as it can reject the opposing dao of the Confucians and Mohists. It provides no alternative that can be outlined through direct logical argument, only through indirect allegory. The Zhuangzi "deconstructs" the Confucians and Mohists, only to shift the discussion and make room for its positive project of spiritual transformation.

The project begins with survival, something most people would like to have but morality cannot guarantee. Dao ensures survival, but it does not involve following explicit rules of conduct. At times, the Sage appears skillful; at others, useless. And in the end, the Sage does not even care about the difference between life and death. 
But it is not enough to begin with an apathy for life and death, for the Sage's knowledge is not intellectual. That is, it is not a matter of simply attaching a truth value to propositions like "every 'this" implies a "that," or "“life' is inextricably liked with 'death."' If it were, there would be no need for flowery metaphors and crazy paradoxes. The metaphors and paradoxes emphasize that one attains survival only through a process of personal transformation, involving a more intuitive knowledge of the unity of opposites in dao. This is ming.

Thus, the Zhuangzi embodies both philosophical disputation and mystical imagery, and both are important in understanding "clarity" and "survival" in the text. In a sense, then, philosophy and mysticism are like correlative opposites in the Zhuangzi. Since it cannot be silent, the Zhrangzi does its best to embrace them both. 


\section{Bibliography}

Ames, Roger T. "Death as Transformation in Classical Daoism," in Death and Philosophy, eds. Jeff Malpas and Robert C. Solomon, 57-70. New York: Routledge, 1998.

Becker, Ernest. The Denial of Death. New York: The Free Press, 1973.

Brooks, E. Bruce and Tacko Brooks. The Original Analects: Sayings of Confucius and His Successors. New York: Columbia University Press, 1998.

Callahan, William A. "Cook Ding's Life on the Whetstone: Contingency, Action, and Inertia in the Zhuangzi," in Wandering at Ease in the Zhuangzi, ed.

Roger T. Ames. 175-196. Albany: SUNY, 1998.

Creel, Herlee G. "On Two Aspects of Early Taoism," in What is Taoism?, 37-47. Chicago: Chicago University Press, 1970.

Cua, Antonio S. "Forgetting Morality: Reflections on a Theme in Chuang-tzu." Journal of Chinese Philosophy 4.4 (1977): 305-328.

Eno, Robert. "Cook Ding's Dao and the Limits of Philosophy," in Essays on Skepticism, Relativism, and Ethics in the Zhuangzi, eds. Paul Kjellberg and Philip J. Ivanhoe, 127-151. Albany: SUNY, 1996.

Fox, Alan. "Reflex and Reflexivity: Wrwei in the Zhuangzi." Asian Philosophy 6.1 (1996): 59-72.

Fraser, C. J. Review of Classifying the Zhuangzi Chapters, by Liu Xiaogan Asian Philosophy 7.2 (1997): 155-159. 
Graham, A. C., "How Much of Chuang-tzu Did Chuang-tzu Write?," in Studies in Chinese Philosophy and Philosophical Literature, 283-321. Albany: SUNY Press, 1990.

Hall, David L. and Roger T. Ames. Thinking Through Confucius. Albany, SUNY 1987. Hansen, Chad. "A Tao of Tao in Chuang-tzu," in Experimental Essays on Chuang-tzu, ed. Victor H. Mair, 24-55. Honolulu: Center for Asian and Pacific Studies, University of Hawaii, 1983.

- A Daoist Theory of Chinese Thought: A Philosophical Interpretation. Oxford: Oxford University Press, 1992.

Ivanhoe, Philip J. "Was Zhuangzi a Relativist?," in Essays on Skepticism, Relativism, and Ethics in the Zhuangzi, eds. Paul Kjellberg and Philip J. Ivanhoe, 196214. Albany: SUNY, 1996.

Lau, D.C., tr. Mencius. New York: Penguin Books, 1970.

—. The Analects. New York: Penguin Books, 1979.

Lewis, Mark Edward. Writing and Authority in Early China. Albany: SUNY Press, 1999.

Liu Xiaogan. Classifying the Zhuangzi Chapters. Anne Arbor. Center for Chinese Studies, University of Michigan, 1994.

Mair, Victor $\mathrm{H}$, trans., Wandering on the Way: Early Taoist Tales and Parables of Chuang Tzu. Honolulu: University of Hawaii Press, 1998.

Major, John S. "The Efficacy of Uselessness: A Chuang-tzu Motif," Philosophy East and West 25 (1976): 265-279. 
Peirce, C. S. "How to Make Our Ideas Clear." Popular Science Vol. 12 (1878): 286-302. Reprinted in Contemporary Analytic and Linguistic Philosophies, ed. E. D.

Klemke, 55-70. Amherst, NY: Prometheus Books, 1983.

Radice, Thomas. "Clarity and Survival in the Zhuangzi." Asian Philosophy 11.1 (2001): 33-40.

Ryle, Gilbert. "On Forgetting the Difference Between Right and Wrong," in Essays in Moral Philosophy, ed. A. I. Melden, 21-40. Seattle: University of Washington Press, 1958.

Van Norden, Bryan W., tr. "Mengzi," in Readings in Classical Chinese Philosophy, eds. Philip J. Ivanhoe and Bryan W. Van Norden, 111-155. New York: Seven Bridges Press, 2001.

Watson, Burton, tr. Mo Tzu: Basic Writings. New York: Columbia University Press, 1963.

—. The Complete Works of Chuang Tzu. New York: Columbia University Press, 1968.

Waley, Arthur, tr. The Analects of Confucius. New York: Macmillan, 1938. Reprint, New York: Vintage Books, 1989.

Wittgenstein, Ludwig. Tractatus Logico-Philosophicus. Translated by D. F. Pears and B. F. McGuinness. New York: Routledge, 1974.

Yearley, Lee. "The Perfected Person in the Radical Chuang-tzu," in Experimental Essays on Chuang-tzu, ed. Victor H. Mair, 125-139. Honolulu: Center for Asian and Pacific Studies, University of Hawaii, 1983. 
-7. "Zhuangzi's Understanding of Skillfulness and the Ultimate Spiritual State," in Essays on Skepticism, Relativism, and Ethics in the Zhuangzi, eds. Paul Kjellberg and Philip J. Ivanhoe, 152-182. Albany: SUNY, 1996. 